\title{
Implantacja stentu do lewej tętnicy płucnej monitorowana angiografią rotacyjną z trójwymiarową rekonstrukcją
}

\author{
Left pulmonary artery stent implantation guided \\ with three-dimensional rotational angiography (3DRA)
}

\author{
Sebastian Góreczny, Paweł Dryżek, Jadwiga Anna Moll, Tomasz Moszura \\ Klinika Kardiologii Instytutu Centrum Zdrowia Matki Polki w Łodzi
}

\section{Streszczenie}

Postępowanie lecznicze u pacjentów z zespołem hipoplazji lewej części serca (HLHS) jest oparte na wieloetapowym leczeniu operacyjnym, niejednokrotnie uzupełnionym dodatkowymi zabiegami interwencyjnymi. W tej grupie pacjentów szczególnie znaczenie ma prawidłowy rozwój łożyska płucnego, który należy do podstawowych czynników obniżających ryzyko powikłań w trakcie kolejnych etapów leczenia. Zabiegi przezskórnego poszerzenia tętnic płucnych pozwalają na optymalizację przepływu płucnego krwi, jednak wykonywane u najmłodszych pacjentów stanowią duże wyzwanie i wymagają znacznej precyzji. Angiografia rotacyjna z trójwymiarową rekonstrukcją (3DRA) to nowa metoda obrazowania umożliwiająca szczegółowe, przestrzenne uwidocznienie anatomii tętnic płucnych nieosiągalne w standardowej angiografii. W prezentowanym przypadku pacjenta z czynnościowo pojedynczą komorą oraz hipoplazją tętnic płucnych 3DRA okazała się pomocna przy kwalifikacji, monitorowaniu oraz końcowej ocenie implantacji stentu wewnątrznaczyniowego. Słowa kluczowe: zespół hipoplazji lewego serca, obrazowanie, leczenie interwencyjne

(Folia Cardiologica 2015; 10, 1: 49-54)

\section{Wstęp}

Postępowanie lecznicze u pacjentów z zespołem hipoplazji lewej części serca (HLHS, hypoplastic left heart syndrome) jest oparte na wieloetapowym leczeniu operacyjnym, niejednokrotnie uzupełnionym dodatkowymi zabiegami interwencyjnymi [1, 2]. W tej grupie pacjentów szczególnie znaczenie ma prawidłowy rozwój łożyska płucnego, który należy do podstawowych czynników zmniejszających ryzyko powikłań w trakcie kolejnych etapów leczenia [3]. Zabiegi przezskórnego poszerzenia tętnic płucnych pozwalają na optymalizacje przepływu płucnego krwi, jednak wykonywane u najmłodszych pacjentów stanowią duże wyzwanie i wymagają znacznej precyzji [4]. Angiografia rotacyjna z trójwymiarową rekonstrukcją (3DRA, three-dimensional rotational angiography) jest nową metodą szczegółowej wizualizacji tętnic płucnych łączącą zalety standardowej angiografii z trójwymiarowym obrazowaniem dostępnym dotychczas $w$ badaniach tomografii komputerowej lub rezonansu magnetycznego [5].

\section{Opis przypadku}

Dwuletniego chłopca z HLHS, po operacji metodą Norwooda w okresie noworodkowym oraz operacji dwukierunkowego zespolenia sposobem Glenna wykonanej w 6. miesiącu życia, zakwalifikowano do diagnostycznego cewnikowania serca przed ostatnim etapem leczenia chirurgicznego - operacją metodą Fontana. Zabieg wykonano w znieczuleniu ogólnym z nakłucia prawej żyły szyjnej wewnętrznej. Po podaniu standardowej dawki antybiotyku (amoksycylina $30 \mathrm{mg} /$ /kg mc.) oraz heparyny niefrakcjonowanej (100 jm./kg mc.) 


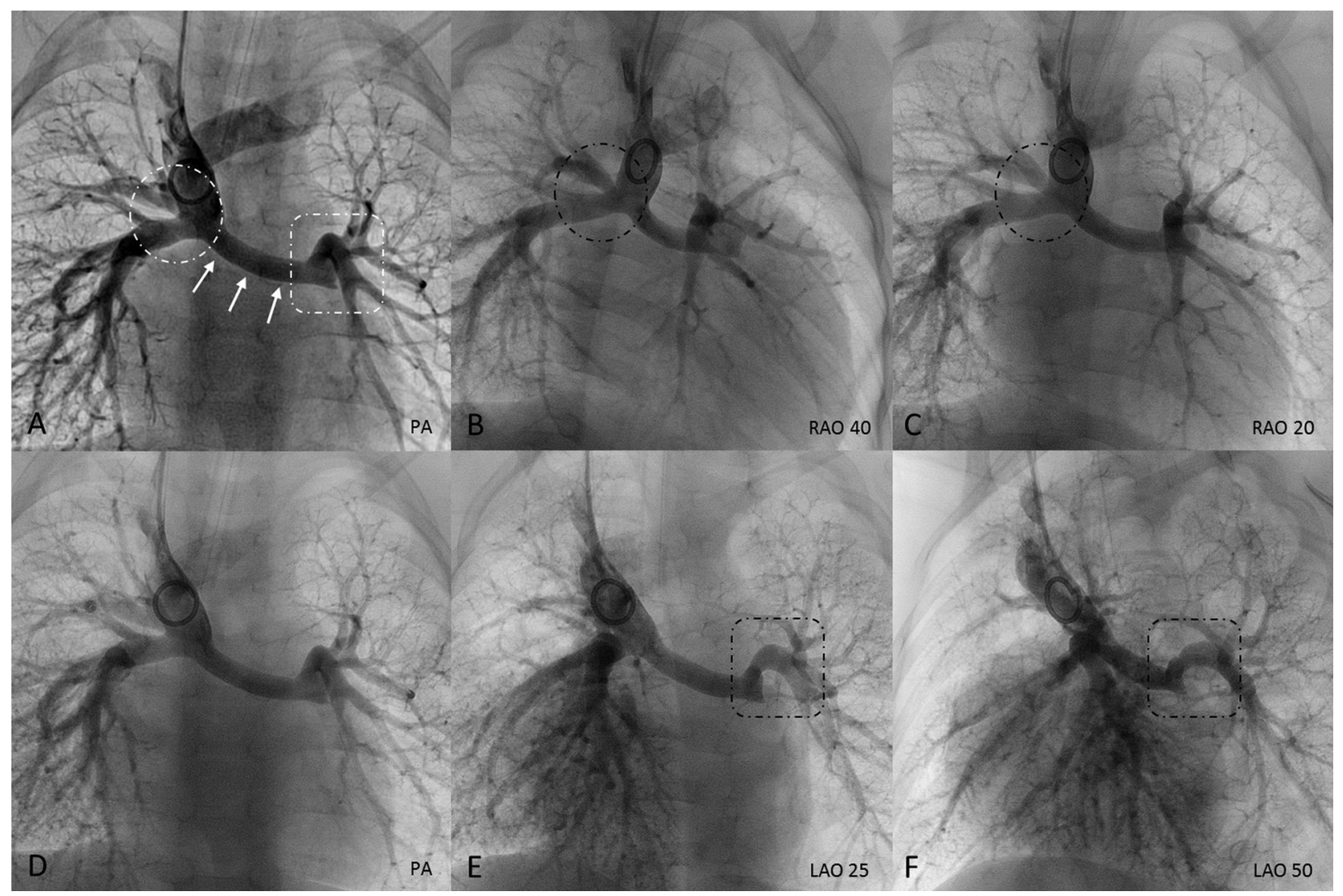

Rycina 1A. Standardowa angiografia, projekcja tylno-przednia (PA, postero-anterior). Widoczna długoodcinkowa hipoplazja bliższego odcinka prawej tętnicy płucnej (białe strzałki). Dalszy segment prawej tętnicy płucnej (białe koło) zasłaniają żyła główna górna oraz zespolenie Glenna. Podobnie początkowy segment lewej tętnicy płucnej (biały kwadrat) nakłada się na bifurkację oraz gałąź płatową dolną; B-F. Angiografia rotacyjna. Wybrane 5 projekcji z łącznej liczby 122. Projekcje prawe skośne (RAO, right anterior oblique) (B, C) eksponują dalszy odcinek prawej gałęzi tętnicy płucnej (czarne koło), natomiast projekcje lewe skośne (LAO, left anterior oblique) (E, F) prezentują szczegółowo lewą gałąź tętnicy płucnej (czarny kwadrat) z widocznym istotnym zwężeniem w odcinku bliższym. Projekcja PA (E) dostarcza zbliżonych informacji w porównaniu ze standardową angiografią (A), jednak ze względu na mniejszą szybkość przepływu środka kontrastowego oraz odmienne parametry akwizycji naczynia cechują się mniejszym wysyceniem

cewnikiem diagnostycznym wykonano pomiary hemodynamiczne: prawa tętnica płucna - 14/12/13 $\mathrm{mm} \mathrm{Hg}$, lewa tętnica płucna - 14/11/12 mm Hg, aorta - 89/48/58 mm Hg. Następnie cewnik angiograficzny umieszczono w żyle głównej górnej i wykonano standardową angiografię, w której uwidoczniono znaczną hipoplazję prawej tętnicy płucnej na odcinku od bifurkacji do zespolenia z żyłą główną górną (ryc. 1A). Z powodu ograniczonego uwidocznienia lewej tętnicy płucnej oraz konieczności uzyskania dodatkowych informacji dotyczących przebiegu obu naczyń przed kwalifikacją do leczenia interwencyjnego wykonano 3DRA. W trakcie czterosekundowego obrotu ramienia angiografu Phillips Allura (Phillips Healthcare) od położenia prawego skośnego $120^{\circ}$ do lewego skośnego $120^{\circ}$ podano $24 \mathrm{ml}$ (2 ml/kg mc.) środka kontrastowego (Iomeron 400, Bracco Imaging). Uwidoczniono swobodny przepływ kontrastu przez zespolenie żyły głównej górnej z dobrze rozwiniętym dalszym odcinkiem prawej tętnicy płucnej, której średnicę
(8 mm) zmierzono tuż przed podziałem na gałęzie płatowe (ryc. 1B, C). Jednocześnie zarejestrowano hipoplazję bliższego odcinka prawej $(5 \mathrm{~mm})$ i lewej $(3,5 \mathrm{~mm})$ tętnicy płucnej oraz dalszego segmentu lewej tętnicy płucnej $(6,5 \mathrm{~mm}$; ryc. 1D-F). Następnie przeprowadzono szczegółową analizę trójwymiarowej rekonstrukcji tętnic płucnych z wyborem miejsca implantacji stentu oraz optymalnej projekcji do monitorowania wprowadzania oraz rozprężenia implantu (ryc. 2). W obwodowej gałęzi lewej tętnicy płucnej umieszczono prowadnik teflonowy J 0,035", po którym implantowano stent Palmaz Genesis $8 \times 24$ mm (Cordis, Johnson and Johnson), uzyskując jego całkowite rozprężenie ciśnieniem 8 atm. W kontrolnej 3DRA potwierdzono optymalne położenie implantu, z dalszym końcem umieszczonym tuż przed podziałem lewej tętnicy płucnej na gałęzie płatowe (ryc. 3). Zdecydowano o odstąpieniu od implantacji stentu do bliższego odcinka prawej tętnicy płucnej, pozostawiając ten segment naczynia do interwencji chirurgicznej w trakcie 


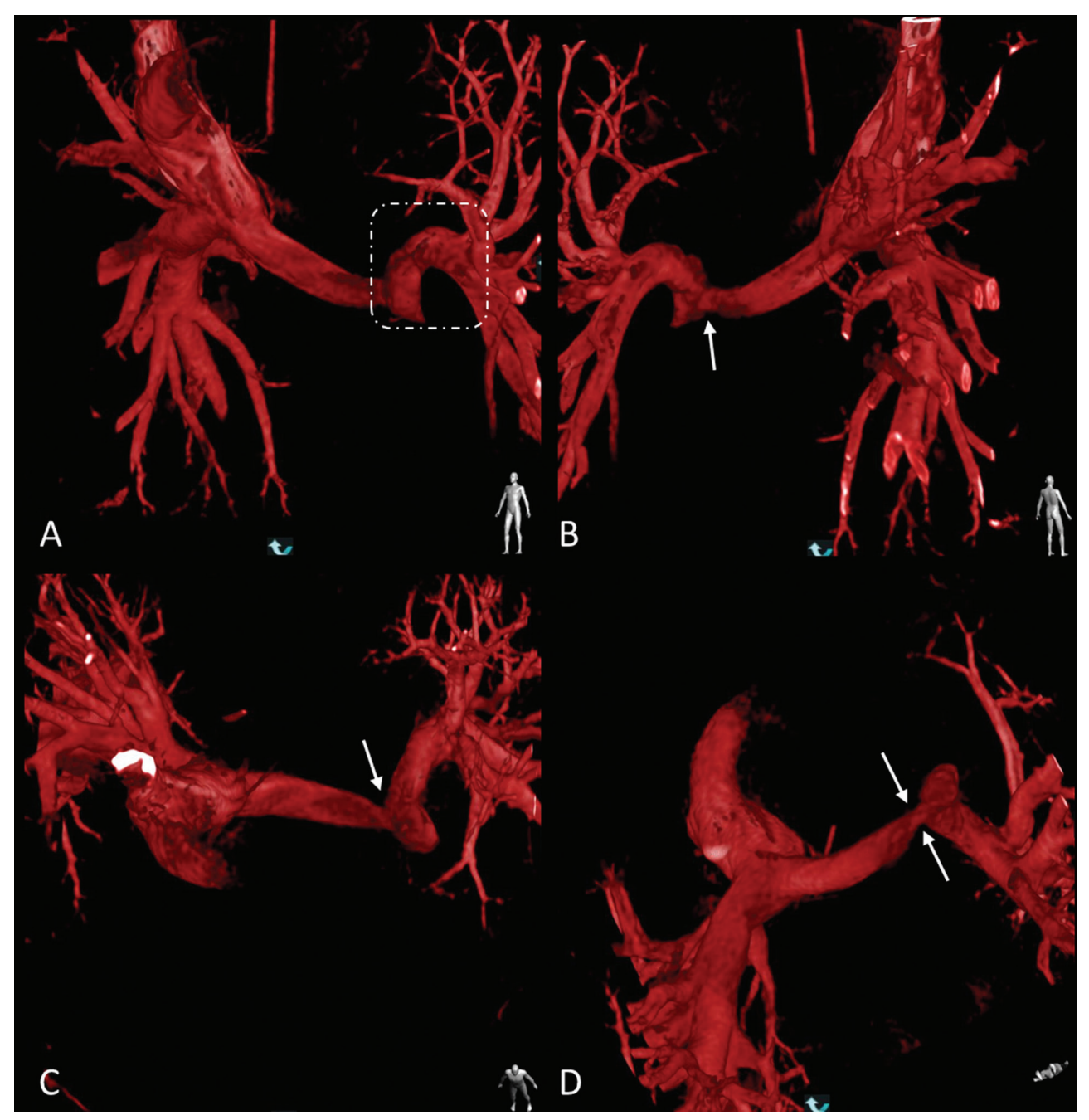

Rycina 2. Trójwymiarowa rekonstrukcja tętnic płucnych na podstawie angiografii rotacyjnej. Postać w prawym dolnym rogu prezentuje perspektywę, z której są analizowane tętnice płucne: A. W płaszczyźnie odpowiadającej projekcji lewej skośnej $35^{\circ} \mathrm{W}$ standardowej angiografii dobrze widoczne są początkowy odcinek lewej tętnicy płucnej (biały kwadrat) oraz miejsce podziału na gałęzie płatowe, szczególnie istotne w przypadku precyzyjnego pozycjonowania stentu; B-D. Płaszczyzny niedostępne w standardowej angiografii oraz angiografii rotacyjnej prezentują, niewidoczne dotychczas, zwężenie (biała strzałka) prawej tętnicy płucnej w odcinku bliższym. Szczególnie zmodyfikowana płaszczyzna pozioma (D) uwidacznia istotne zwężenie prawej tętnicy płucnej w wymiarze przednio-tylnym (białe strzałki) niewidoczne w angiografii

operacji metodą Fontana. W dalszym przebiegu po zabiegu interwencyjnym nie obserwowano powikłań i po 2 dniach obserwacji chłopca wypisano do domu.

\section{Omówienie}

Mimo udoskonalania technik chirurgicznych, optymalizacji opieki okołooperacyjnej oraz uzupełniających zabiegów interwencyjnych pacjenci z HLHS wciąż stanowią duże wyzwanie dla specjalistów wielu dziedzin, a wyniki leczenia pozostają niezadowalające $[1,2,4]$. Istnieje wiele zdefiniowanych czynników zwiększających ryzyko na poszczególnych etapach leczenia paliatywnego, między innymi: restrykcyjne połączenie międzyprzedsionkowe, zwężenia naczyń płucnych, podwyższone ciśnienie w łożysku płuc- nym, zaburzenia funkcji skurczowo-rozkurczowej systemowej prawej komory [3]. Dlatego, w celu zniwelowania lub ograniczenia przytoczonych czynników ryzyka, już na wczesnych etapach leczenia wskazane jest intensywne postępowanie.

Zwężenia tętnic płucnych, szczególnie lewej, stanowią częste wskazanie do leczenia interwencyjnego bez względu na typ pierwszego etapu paliacji, klasycznej operacji metodą Norwooda lub leczenia hybrydowego [6, 7]. Ze względu na zmianę morfologii tętnic płucnych po leczeniu chirurgicznym, ucisk zewnętrzny ze strony zrekonstruowanej aorty lub sąsiadującego lewego oskrzela oraz zrosty powodujące napięcia naczyń izolowana angioplastyka balonowa rzadko umożliwia uzyskanie trwałych efektów [4]. Implantacja stentu pozwala na skuteczne i trwałe zwiększenie 


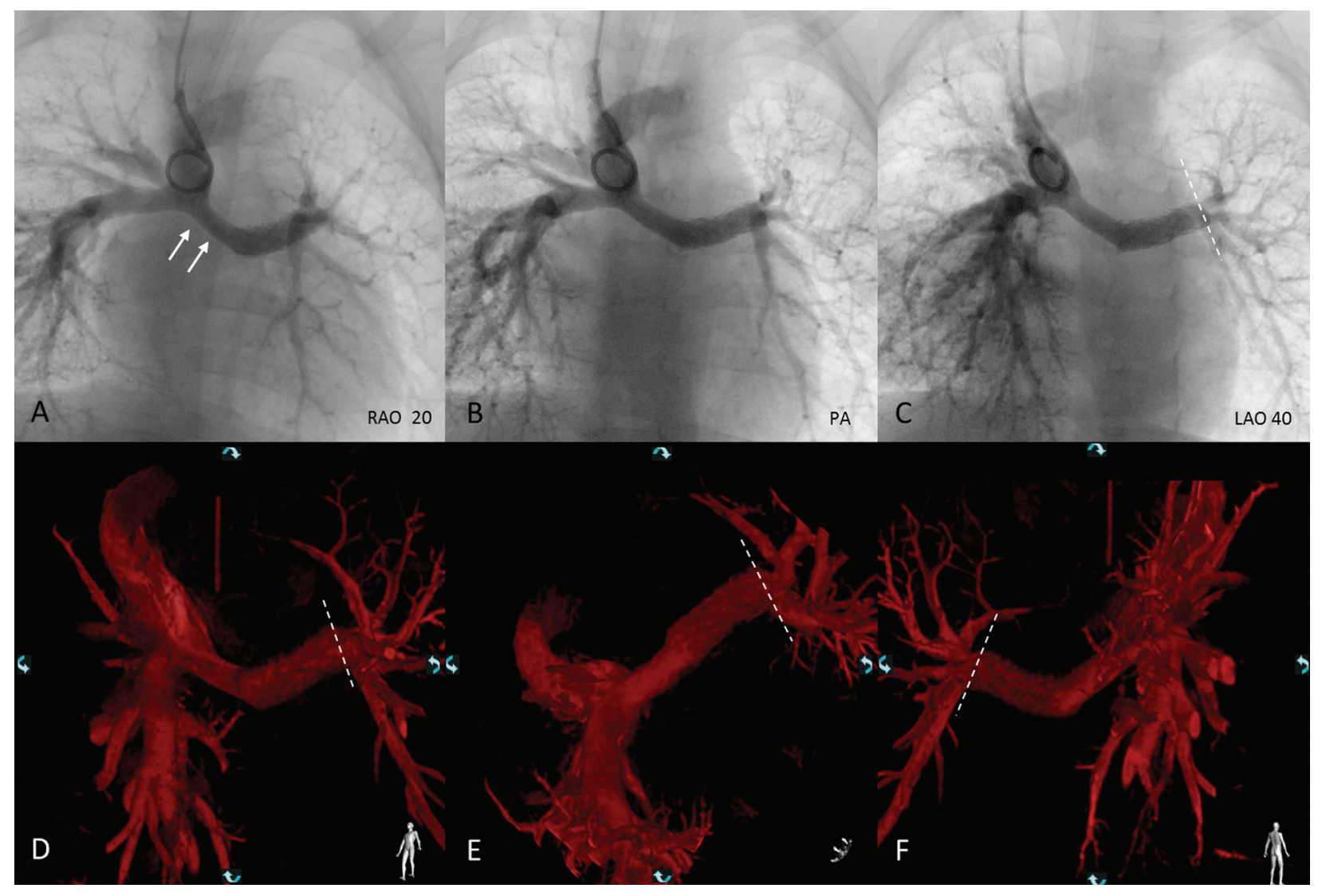

Rycina 3. W kontrolnej angiografii rotacyjnej (A-C) po leczeniu interwencyjnym widać optymalnie położony stent z dalszym końcem (biała linia przerywana) tuż przed podziałem lewej tętnicy płucnej na gałęzie płatowe. Węższy odcinek prawej tętnicy płucnej (białe strzałki) pozostawiono do interwencji chirurgicznej w trakcie ostatniego etapu leczenia chirurgicznego. Rekonstrukcja trójwymiarowa (D-E) pozwala na bardziej szczegółową ocenę wyniku leczenia, prezentując tętnice płucne z implantowanym stentem między innymi od dołu (E) oraz od tyłu (F); RAO (right anterior oblique) - projekcja prawa skośna; PA (postero-anterior) - projekcja tylno-przednia; LAO (left anterior oblique) - projekcja lewa skośna

wymiaru tętnic płucnych, jednak ma liczne ograniczenia. Podstawową wadą takiego rozwiązania jest konieczność kilkukrotnego doprężania implantu, aby dostosować jego średnicę do wzrostu pacjenta. Dodatkowo u najmłodszych pacjentów istotne jest prawidłowe pozycjonowanie stentu tak, aby poszerzyć odpowiedni fragment naczynia, a jednoczenie nie utrudnić napływu do sąsiadujących odgałęzień.

Odpowiednia wizualizacja tętnic płucnych stanowi podstawowy warunek prawidłowej kwalifikacji do interwencji przezskórnej, a następnie wyboru odpowiedniej techniki oraz sprzętu [5]. U pacjentów po operacji metodą Glenna, z uwagi na względnie wolny przepływ krwi, małą skurczowo-rozkurczową różnicę wymiarów tętnic płucnych oraz zwykle brak dodatkowych źródeł wypłukiwania środka kontrastowego, zastosowanie 3DRA pozwala na uzyskanie dużej liczby (do 122 projekcji) wysokiej jakości obrazów naczyń płucnych. U prezentowanego pacjenta projekcje lewe skośne z angiografii rotacyjnej pozwoliły na szczegółową ocenę lewej tętnicy płucnej. Dodatkowo trójwymiarowa rekonstrukcja umożliwiła analizę tętnic płucnych w niestandardowych projekcjach, nieosiągal- nych w typowej angiografii, co pozwoliło na rozpoznanie istotnego zwężenia prawej tętnicy płucnej. Trójwymiarowa rekonstrukcja okazała się również przydatna do wyboru optymalnej projekcji do monitorowania procedury wszczepienia implantu oraz do szczegółowej oceny wyniku postępowania interwencyjnego.

\section{Podsumowanie}

Angiografia rotacyjna z trójwymiarową rekonstrukcją pozwala na szczegółowe, przestrzenne uwidocznienie anatomii tętnic płucnych nieosiągalne w standardowej angiografii. W prezentowanym przypadku pacjenta z czynnościowo pojedynczą komorą oraz hipoplazją tętnic płucnych 3DRA okazała się pomocna przy kwalifikacji, monitorowaniu oraz końcowej ocenie implantacji stentu wewnątrznaczyniowego.

\section{Konflikt interesów}

Autorzy nie zgłaszają konfliktu interesów. 


\section{Abstract}

Patients with hypoplastic left heart syndrome require multistage surgical treatment, often supported with additional percutaneous interventions. In this population normal development of pulmonary vasculature is crucial, as it belongs to key factors reducing complication rate at all stages of palliation. Transcatheter interventions allow for significant improvement of pulmonary blood flow but they can be very challenging in the youngest patients. Three-dimensional rotational angiography (3DRA) is an emerging imaging modality that enables detailed visualization of pulmonary arteries, not achievable in standard angiography. In presented patient with univentricular heart and pulmonary artery hypoplasia 3DRA proved helpful in qualification, monitoring and final evaluation of stent implantation.

Key words: hypoplastic left heart syndrome, imaging, percutaneous intervention

(Folia Cardiologica 2015; 10, 1: 49-54)

\section{Piśmiennictwo}

1. Rychik J. Hypoplastic left heart syndrome: can we change the rules of the game? Circulation 2014; 130: 629-631.

2. Moszura T., Góreczny S., Dryżek P. Hypoplastic left heart syndrome a review of supportive percutaneous treatment. Post. Kardiol. Interw. 2014; 10: 201-208.

3. Hosein R.B., Clarke A.J., McGuirk S.P. i wsp. Factors influencing early and late outcome following the Fontan procedure in the current era. The ‘Two Commandments'? Eur. J. Cardiothorac. Surg. 2007; 31: 344-352.

4. Moszura T., Dryżek P., Góreczny S. i wsp. A 10-year single-centre experience in percutaneous interventions for multi-stage treatment of hypoplastic left heart syndrome. Cardiol. Young 2014; 24: 54-63.
5. Berman D.P., Khan D.M., Gutierrez Y., Zahn E.M. The use of three-dimensional rotational angiography to assess the pulmonary circulation following cavo-pulmonary connection in patients with single ventricle. Catheter Cardiovasc. Interv. 2012; 80: 922-930.

6. Sharma V., Deo S.V., Huebner M. i wsp. In search of the ideal pulmonary blood source for the Norwood procedure: a meta-analysis and systematic review. Ann. Thorac. Surg. 2014; 98: 142-150.

7. Dave H., Rosser B., Knirsch W. i wsp. Hybrid approach for_hypoplastic left heart syndrome_and its variants: the fate of the pulmonary arteries. Eur. J. Cardiothorac. Surg. 2014; 46: 14-19.

\section{Komentarz}

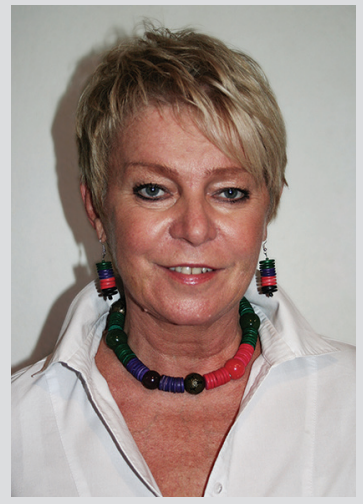

\section{dr hab. n. med. Grażyna Brzezińska Rajszys}

Pracownia Interwencji Sercowo-Naczyniowych Instytutu „Pomnik - Centrum Zdrowia Dziecka" w Warszawie

Wykorzystanie angiografii rotacyjnej do monitorowania zabiegów interwencyjnych u dzieci z wadami serca nie tylko w Polsce jest dość rzadkie, dlatego poświęcona temu tematowi kazuistyczna praca pochodząca z najbardziej doświadczonego w tym zakresie Ośrodka sprowokowała poniższy komentarz.

Obrazowanie wad serca z trójwymiarową rekonstrukcją (3D, three-dimensional) obrazu echokardiograficznego, tomografii komputerowej (CT, computed tomography), rezonansu magnetycznego (MRI, magnetic resosonance imaging), a ostatnio angiografii rotacyjnej (3DRA, three-dimensional rotational angiography) weszło do standardu diagnostycznego wad układu sercowo-naczyniowego, uszczegółowiając i uzupełniając informacje - przede wszystkim dotyczące relacji przestrzennych poszczególnych struktur wewnątrzsercowych, naczyniowych oraz wykazując ich położenie względem innych narządów klatki piersiowej, zwłaszcza oskrzeli. Szczególnie ważne z punktu widzenia złożonych wrodzonych wad serca są zmiany dotyczące aorty i krążenia płucnego, przede wszystkim zwężenia tętnic płucnych i ich odgałęzień. Morfologia zwężeń, z dokładnymi pomiarami ich zakresu i rozległości, ma szczególne znaczenie dla leczenia interwencyjnego - wielokrotnie jedynej opcji terapeutycznej. Szczególnie istotne są zwężenia tętnic płucnych u pacjentów z najbardziej złożonymi wadami serca leczonymi wieloetapowo metodą Fontana. Ponieważ tak zwane krążenie fontanowskie - efekt połączenia różnymi technikami chirurgicznymi żył systemowych z tętnicami płucnymi - jest krążeniem niskociśnieniowym, to jego efektywność hemodynamiczna w istotnej mierze zależy od płucnego oporu naczyniowego. 
W tym typie krążenia nawet niewielkie zmiany anatomiczne w zakresie tętniczego łożyska płucnego, $w$ tym zwężenia pooperacyjne, podgięcia naczyń czy zwężenia wtórne do ucisku z zewnątrz (najczęściej przez poszerzoną aortę lub neoaortę) powodujące gradient ciśnienia, często nieprzekraczający $5 \mathrm{~mm} \mathrm{Hg}$, mogą powodować istotne zaburzenia hemodynamiczne z ciężką niewydolnością krążenia. Poszerzenie zwężeń, najczęściej poprzez przeznaczyniową implantację stentów, jest w tych przypadkach leczeniem z wyboru. Precyzja zabiegu zależy od szczegółowej diagnostyki zmian. Obrazowanie tętnic płucnych w klasycznej angiografii, nawet z zastosowaniem kilku projekcji, może być obciążone błędem, przede wszystkim ze względu na skracanie projekcyjne obrazu odgałęzień przebiegających w różnych płaszczyznach oraz nakładanie się naczyń (typowe ograniczenia obrazowania 2D obiektów 3D). W sytuacji, w której przezskórne leczenie wybranych wad wrodzonych układu sercowo-naczyniowego oraz zmian pozabiegowych jest powszechnie zaakceptowane, a zakres zabiegów wykonywanych u pacjentów od okresu noworodkowego - coraz szerszy, poszukiwanie możliwości wykorzystania obrazów 3D w czasie zabiegów jest w pełni uzasadnione. Umieszczenie na ekranie fluorokopii obrazu 3D leczonej patologii, z uwzględnieniem optymalnej dla prowadzenia zabiegu projekcji poprzez ich precyzyjne nałożenie, w sposób oczywisty ułatwia wykonanie zabiegu. Z technicznego punktu widzenia istnieją możliwości wykorzystania praktycznie wszystkich rodzajów przedzabiegowych obrazów w czasie zabiegów interwencyjnych [1-4], chociaż 3DRA wydaje się najbardziej logicznym i najprostszym rozwiązaniem [5-7]. Uzyskany w czasie około $4 \mathrm{~s}$ rotacji lampy rentgenowskiej, w czasie jednorazowego podania środka kontrastowego, obraz angiograficzny rejestrowany w czasie rzeczywistym stanowi zbiór obrazów dwuwymiarowych, który po opracowaniu komputerowym zostaje zrekonstruowany do obrazu trójwymiarowego. Stosowanie w czasie angiografii zatrzymania oddechu oraz szybkiej stymulacji serca wraz z odpowiednim protokołem dotyczącym miejsca podania kontrastu, jego objętości i czasu, wpływają na jakość obrazu i są modyfikowane, między innymi zależnie od patologii, prędkości przepływu krwi w obszarze diagnozowanym oraz doświadczenia. Opisywana metoda dodaje informacje dotyczące morfologii przede wszystkim zmian naczyniowych i uszczegółowia je, umożliwia ocenę wpływu oddziaływania struktur otaczających na okolice diagnozowanej patologii, wybór optymalnej projekcji do prowadzenia zabiegu interwencyjnego, jego nawigacje oraz jednoznaczną ocenę pozabiegowego efektu anatomicznego. Wiele wskazuje na to, że wysokiej jakości 3DRA będzie mogła zastąpić angiografię dwupłaszczyznową. W doświadczonych ośrodkach dawka promieniowania oraz objętość kontrastu konieczne, by uzyskać jednoznaczne obrazy 3DRA w wadach wrodzonych serca, są porównywalne ze stosowanymi w klasycznych badaniach dwupłaszczyznowych przy prędkości akwizycji 15 klatek/s [8]. Ważne, by w ocenie każdej metody diagnostycznej i terapeutycznej wykorzystującej promieniowanie jonizujące pamiętać o tym, że zasady optymalizacji dawki powinny dotyczyć nie tylko wykonywanej procedury, ale wszystkich działań z zastosowaniem promieniowania jonizującego, którym jest poddawany pacjent. Ma to zasadnicze znaczenie dla pacjentów w okresie rozwojowym.

\section{Piśmiennictwo}

1. Krishnaswamy A., Tuzcu E.M., Kapadia S.R. Three-dimensional computed tomography in the cardiac catheterization laboratory. Catheter. Cardiovasc. Interv. 2011; 77: 860-865.

2. Glatz A.C., Zhu X., Gillespie M.J. i wsp. Use of angiographic CT imaging in the cardiac catheterization laboratory for congenital heart disease. JACC Cardiovasc. Imaging 2010; 3: 1149-1157.

3. Dori Y., Sarmiento M., Glatz A.C. i wsp. X-ray magnetic resonance fusion to internal markers and utility in congenital heart disease catheterization. Circ. Cardiovasc. Imaging 2011; 4: 415-424.

4. Glöckler M., Halbfaß J., Koch A. i wsp. Multimodality 3D-roadmap for cardiovascular interventions in congenital heart disease a single-center, retrospective analysis of 78 cases. Catheter. Cardiovasc. Interv. 2013; 82: 436-442.
5. Aldoss 0., Darst J., Fonseca B. i wsp. Diagnostic utility of 3-dimensional rotational angiography in pediatric cardiac catheterization. Catheter. Cardiovasc. Interv. 2013; 81: 180.

6. Fagan T., Neubauer A., Einch S. i wsp. 3-dimensional rotational angiographic roadmapping used to guide congenital cardiac interventions. Catheter. Cardiovasc. Interv. 2011; 78: S190.

7. Zahn E. The emerging use of 3-dimensional rotational angiography in congenital heart disease. Congenital Cardiology Today 2011; 9: 1-13.

8. Reinke G., Halbfaß J., Dittrich S. i wsp. Three-dimensional rotational angiography in congenital heart disease: estimation of radiation exposure. Open J. Radiol. 2013; 3: 124-129. 